\title{
AZ ENSZ EMBERI JOGI TANÁCS MUNKÁJÁNAK KRITIKAI ÉRTÉKELÉSE, AVAGY SZÁMVETÉS TIZENÖT ÉVRŐL ILLÚZIÓK NÉLKÜL**
}

https://doi.org/10.51783/ajt.2021.4.04

Ezen cikk keretei között a szerző számba vette az ENSZ Emberi Jogok Bizottsága hagyatékát és azokat a változásokat, amelyeket az Emberi Jogi Tanáccsal történö felváltása hozott 2006-ban. Egy politikai testület, mint az EJB/EJT, nem tehet többet, mint amit a tagállamok engednek neki, és nem hibáztatható azért, mert politikai megközelítések vezérlik. Mindezek alapján nem volt meglepö, hogy az új intézményi keretek nem oldották meg az EJB-vel kapcsolatos politikai problémákat, hiszen az új testület létszáma szinte teljesen megegyezett a jogelőd testületével, ugyanazon szereplők vettek részt a munkájában, és hasonló politikai feltételek szerint müködött. Az Egyetemes Emberi Jogi Felülvizsgálati Mechanizmus (UPR) életre hívása azonban új megközelitést hozott be az ENSZ rendszerébe azáltal, hogy biztosítja valamennyi ENSZ-tagállam emberi jogi helyzetének kooperatív módon való áttekintését, ezzel egyre fokozottabb szerepet biztositva az ott megfogalmazott ajánlások végrehajtását segítő technikai segítségnyújtási pillérnek. A fentiek ellenére a UPR-folyamat nem tette szükségtelenné az országspecifikus határozatok elfogadását, de azok alkalmazására sokkal inkább stratégiai módon kell sort keríteni, jobb koordinációt biztosítva az ENSZ egész rendszerén belül, a világszervezet munkájában növelve a regionális dimenzió jelentöségét. Politikailag nem reális azt várni, hogy az EJT-tagországok mind kiváló, hibátlan emberi jogi mutatókkal rendelkezzenek, de az emberi jogok iránt elkötelezett, azokat támogató kormányok jelölését bátorítani kellene. Fontos kiemelni, hogy az elmúlt évek során számos érzékeny kérdés kapcsán a WEOG, az EEG, valamint a GRULAC országai, kiegészülve néhány emberi jogokat támogató ázsiai és afrikai országgal, sikeres koalíciókat építettek ki az EJT-ben. A világon megfigyelhető demokratizálódási folyamat-az elmúlt években megfigyelhetö visszaesés ellenére is - tovább erösíti ezeket a pozitív tendenciákat, javítva az EJT összetételét, mivel reményeink szerint mind több és több demokratikus ország próbál majd bekerülni a testületbe.

* PhD, nagykövet, karrier diplomata (jelenleg a montenegrói Igazságügyi, Emberi és Kisebbségi Jogi Minisztérium tanácsadója), Külgazdasági és Külügyminisztérium, 1027 Budapest, Bem rakpart 47. E-mail: lakatistvan@yahoo.com.

** A cikk a szerző angol nyelvű doktori értekezésén alapul. A cikkben kifejtett nézetek a szerző magánvéleményét tükrözik, és nem tekinthetők a Külgazdasági és Külügyminisztérium hivatalos álláspontjának. 
„A legtöbb ember ebben a szobában vagy egy kormánynak dolgozik, vagy kormányzati döntéseket igyekszik befolyásolni munkájával. Ez a politika. Az, hogy egyesek azzal vádolnak másokat, hogy azok politizálnak, kicsit olyan, mint amikor az egyik hal azért kritizálja a másikat, hogy az vizes.”

Sergio Viera de Mello, egykori ENSZ Emberi Jogi Főbiztos ${ }^{1}$ felszólalása az Emberi Jogok Bizottsága ülésén

\section{BEVEZETÉS}

A világ első, univerzális kormányközi emberi jogi testületét, az 1946-ban életre hívott Emberi Jogok Bizottságát (Commission on Human Rights - továbbiakban EJB) működésének utolsó éveiben szinte minden fórumról olyan heves támadások érték, hogy csak idő kérdése volt, mikor dönt a nemzetközi közösség mandátumának megszüntetéséröl. Erre a momentumra 2006-ban került sor, amikor az ENSZ tagállamai végül úgy határoztak hosszas tárgyalásokat követően, hogy az EJB-t felváltják egy új testülettel, az Emberi Jogi Tanáccsal (Human Rights Council - továbbiakban EJT). Ezen írás keretei között röviden szólnék azokról az okokról, amelyek az EJB bukásához vezettek, és előkészítették a talajt az EJT életre hívása előtt, majd részletesen ismertetni kívánom a tizenöt éve megalakult Tanács eddigi munkáját a jelenlegi nemzetközi politikai helyzet tükrében, tekintetbe véve azon új jelenségeket és tendenciákat, amelyek jellemzik napjaink multilaterális emberi jogi diplomáciáját. El kell ismernünk azonban, hogy az EJT még mindig viszonylag fiatal testületnek tekinthető, amely folyamatos változások alatt áll, és olyan kihívásokkal néz szembe, amelyekkel az ENSZ fő szerveinek kellene foglalkozniuk.

\section{AZ ENSZ EMBERI JOGOK BIZOTTSÁGA BUKÁSÁHOZ VEZETŐ ÚT}

A legtöbb kritikus hajlamos elfelejteni, hogy az EJB hatvan évig állt fenn, és ezen időszak alatt megtett minden tőle telhetőt a nemzetközi emberi jogi napirend előmozdítása érdekében, a hidegháború időszakának megszorító feltételei ellenére is. Nem meglepő módon 1945-ben, ${ }^{2}$ az akkori amerikai külügyminiszter, Edward Stettinius az EJB megalakítását tartotta a San Franciscó-i Konferencia egyik legnagyobb eredményének. ${ }^{3}$

1 Michael IgnatiefF: „Rights inflation and role conflict in the Office of the High Commissioner for Human Rights" in Felice D. GAER - Christen L. Broecker (szerk.): The United Nations High Commissioner for Human Rights: Conscience of the World (Leiden and Boston: Martinus Nijhoff Publishers 2014), 41.

2 Az 1945-ös San Franciscó-i Konferencia: https://www.un.org/en/about-us/history-of-the-un/sanfrancisco-conference.

3 Paul Gordon LAUREN: „To preserve and build on its achievements and to redress its shortcomings” The journey from the Commission on Human Rights to the Human Rights Council" Human Rights Quarterly 2007/2. 310., https://doi.org/10.1353/hrq.2007.0020. 
Az ECOSOC (az ENSZ Gazdasági és Szociális Tanácsa) 1946-ban állította fel az EJB-t a saját felügyelete alatt, kezdetben tizennyolc taggal. Az ENSZ tagság bővülésével növekedett az EJB mérete is, és 1962-ben huszonegy före, 1967-ben harminckettőre, míg 1980-ra negyvenhárom főre nőtt a létszáma. Végső nagyságát (ötvenhárom) 1992-ben érte el a testület. ${ }^{4}$ Azonban a kiszolgáló titkárság mérete nem követte ezeket a fejleményeket, és az eredetileg meghatározott éves ülésszak hossza (hat hét) sem változott. ${ }^{5}$

Az EJB egy viszonylag gyenge mandátummal rendelkezett az ENSZ-tagállamok politikai megfontolásainak megfelelően. Egyes szakértők csak ún. „moral talk shop”nak nevezték a testületet. ${ }^{6}$ Az EJB első húsz évét, 1947-67 között a nyugati országok és szövetségeseik dominálták. 1964-ig az EJB-nek nem volt szubszaharai afrikai tagja sem. ${ }^{7}$ Ebben az időszakban az EJB inkább a normaalkotásra és nem az egyes országok emberi jogi politikájának felülvizsgálatára koncentrált. Ezekben az években egyetlen EJB elnököt sem adott a Kelet-európai Csoport (EEG), és az afrikai országok részvétele még minimális volt. ${ }^{8}$ A testület müködésének második időszakában (1967-1979) kezdett kibontakozni annak ellenőrzési szerepe a 1235-ös és 1503-as ECOSOC határozatok elfogadását követően. A következő, 1979-1991 közötti periódusban az EJB-tagok megpróbálták erősíteni ellenőrzési funkcióikat a kedvezőtlen politikai körülmények ellenére is. A hidegháborút követő időszak első felében a szinte konszenzusosan elfogadott határozatok voltak még jellemzők, míg a 2001-2006 közötti második szakaszban már egyre több régiók közötti összecsapásra került sor, és ez vezetett el többek között az EJB EJT-vel való felváltásához is. ${ }^{9}$

Mielőtt ismertetnénk az EJB diszkreditálásához vezető fontosabb tényezőket, le kell szögeznünk, hogy az EJB többet tett, mint akármelyik ENSZ-testület a civil társadalom képviselőinek a nemzetközi emberi jogi diplomáciába történő bevonása érdekében. ${ }^{10} \mathrm{Ez}$ szerencsére az EJT alatt is folytatódott. A fenti eredmények ellenére az EJB müködésének utolsó éveiben a testület heves kritikák tárgyává vált számos csoport részéről. Az első olyan jelzés, amely nyilvánvalóvá tette a problémát a külvilág számára is, 2004-ben történt, ${ }^{11}$ az ENSZ Főtitkár Magasszintű Panelje (UN Secretary-General's High-level Panel on Threats, Challenges and Change,) által jegyzett, Egy biztonságosabb világ: közös felelösségünk (A more secure world:

4 LAUREN (3. lj.) 84.

5 Rosa Freedman: The United Nations Human Rights Council-A Critique and Early Assessment (Abingdon, UK: Routledge 2013) 15., https://doi.org/10.4324/9780203074732.

6 David P. Forsythe - Baekkwan PARK: „The changing of the guard: From the UN Human Rights Commission to the Council" Human Rights Law Journal 2008/1-5. 4.

7 Kevin Boyle: „The United Nations Human Rights Council: Origins, antecedents, and prospects” in Kevin Boyle (szerk.): New Institutions for Human Rights Protection (Oxford, UK: Oxford University Press 2009). 22., https://doi.org/10.1093/acprof:oso/9780199570546.003.0002.

8 BOYle (7. lj.) 26.

9 Forsythe-Park (6. lj.) 4 .

10 Lauren (4. lj.) 324.

11 Patricia Scannella - Peter Splinter: „The United Nations Human Rights Council: A promise to be fulfilled" Human Rights Law Review 2007/1, 42., https://doi.org/10.1093/hrlr/ngl036. 
our shared responsibility) címet viselő jelentésének publikálásával, ${ }^{12}$ és Kofi Annan Nagyobb szabadságban: a biztonság, a fejlődés és univerzális emberi jogok felé (In larger freedom: towards development, security and human rights for all) (2005) ${ }^{13}$ címü, erre történt válaszának megjelenésével.

Az EJB EJT-vel történő felváltásához vezető folyamat azonban néhány évvel korábban kezdődött. 2001 májusa egy fontos mérföldkövet jelentett ebben a tekintetben, mivel ez volt az az alkalom, hogy az USA elvesztette a helyét az EJB-ben. Ebben az évben négy jelölt ország pályázott a WEOG ${ }^{14}$ részére rendelkezésre álló három helyre, három európai ország, valamint az Egyesült Államok és a fejlődő országok többsége a három európai országot segítette az EJB-be az USA-val szemben. 2003-ban, amikor az Egyesült Államokat újra beválasztották a testületbe, Washington intenzív kampányba kezdett azon gyakorlattal szemben, hogy kétes emberi jogi helyzetủ országokat válasszanak be a Bizottságba. Ebben az évben az EJB a líbiai nagykövetet választotta meg a testület elnökének Washington minden tiltakozása ellenére, leszavazva az amerikai delegációt a kérdésben kezdeményezett szavazás során. ${ }^{15}$

A hidegháború végeztével kialakult politikai vákuumot regionális konfrontációk töltötték be, felváltva a Kelet-Nyugat megosztottságot. Az EJB egyre bővülő tagságával párhuzamosan a testület napirendje is egyre szélesebbé vált, és abban egyre több országspecifikus kezdeményezés kapott helyet, amely természetesen hozzájárult a testület munkájának átpolitizáltságához. Ennek eredményeként a Bizottságot egyre gyakrabban vádolták kettős mérce alkalmazásával az ENSZ tagállamok emberi jogi helyzetének vizsgálata során. ${ }^{16} \mathrm{Az}$ ENSZ legfontosabb emberi jogi testülete egyre több időt fordított eljárási vitákra és az ún. no action motion (annak kezdeményezése, hogy az EJB/EJT ne hozzon határozatot egy adott kérdésben) alkalmazására, amely révén befolyásos tagállamok, mint például Kína az EJB munkáját blokkolták bizonyos országhelyzetek vitája során. Volt néhány próbálkozás a testület alapvető reformjára, de végül csak mérsékelt változásokat fogadtak el a tagállamok a napirend és a munkamódszerek tekintetében.

Annak ellenére, hogy a civil szervezetek egyedülálló privilégiumokat élveztek az EJB-ben, az NGO-k egyre hangosabban kezdték el kritizálni a testületet azért, hogy az nem tűzött napirendre fontos emberi jogi problémákat a kettős mérce alkalmazása miatt. Sok ország volt kritikus amiatt is, hogy a P5-ök (a Biztonsági Tanács öt vétó-

12 The Secretary-General's High-level Panel Report on Threats, Challenges and Change, A more secure world: our shared responsibility, https://www.un.org/ruleoflaw/blog/document/the-secretarygenerals-high-level-panel-report-on-threats-challenges-and-change-a-more-secure-world-ourshared-responsibility.

${ }^{13}$ In larger freedom: towards development, security and human rights for all: Report of the SecretaryGeneral. https://www.un.org/ruleoflaw/blog/document/in-larger-freedom-towards-development-security-and-human-rights-for-all-report-of-the-secretary-generaV.

14 WEOG - Nyugat Európai és Egyéb Államok Csoportja.

15 Boyle (7. lj.) 27.

${ }^{16}$ Maximilian Spohr: „United Nations Human Rights Council. Between institution-building phase and review of status" in A. Von Bogdandy - R.Wolfrum (szerk.): Max Planck Yearbook of United Nations Law, 2010. 173. 
joggal rendelkező állandó tagja - Amerikai Egyesült Államok, Kínai Népköztársaság, Oroszországi Föderáció, Egyesült Királyság, Franciaország) emberi jogi problémái (Tibet, Csecsenföld vagy Guantánamo) sohasem kerültek az EJB napirendjére. Kofi Annan az egész helyzetet „hitelességi deficitként” írta le. ${ }^{17}$

Ez a hitelességi deficit részben azért is alakult ki, mert számos rossz emberi jogi helyzettel rendelkező ország azért szeretett volna mindenképpen bekerülni a testületbe, hogy megvédje magát a nemzetközi kritikákkal szemben. Tekintettel a nagyon laza tagsági kritériumokra, viszonylag egyszerű feladat volt huszonnyolc támogató szavazatot szerezni az ötvennégy fős ECOSOC-on belül. ${ }^{18}$

Kofi Annan explicit kijelentette, hogy az átpolitizáltság és a szelektivitás aláásták az EJB hitelességét, és így az ENSZ egészének reputációjára is negatív hatással voltak. Ennek következtében javasolta egy új testület, az EJT felállítását. ${ }^{19}$

Összefoglalóan, a nemzetközi közösség elkezdett felkészülni az EJB egy új testülettel való felváltására, annak érdekében, hogy több idő legyen az ülésekre, hogy javuljon a testület tagságának összetétele, hogy könnyebb legyen olyan válságokkal foglalkozni, amelyek az ülésszakok között alakulnak ki, és hogy a testület státuszát megemelje. ${ }^{20}$ A nemzetközi közösségnek az volt a célja az EJT-vel, hogy az túllépjen a szelektivitáson, az átpolitizáltságon és a kettős mérce gyakorlatán, amelyek az EJB-re voltak jellemzők. ${ }^{21}$ A politikai döntés az EJB EJT-vel történő felváltására a 2005. szeptemberi Világ Csúcstalálkozón született meg. ${ }^{22}$ (Az Emberi Jogi Tanács megalakulásával és intézményeivel kapcsolatos részletesebb elemzés olvasható a szerző korábbi cikkeiben. ${ }^{23}$ )

17 Yvonne Teruingen: „The Human Rights Council: A new era in UN human rights work?” Ethics and International Affairs 2007. 21/2. 169.

18 Mathew Davies: „Rhetorical Inaction? Compliance and the Human Rights Council of the United Nations" Alternatives 2010, https://doi.org/10.1177/030437541003500406.

${ }^{19}$ Ladan Rahmani-Ocara: „Giving the Emperor real clothes: The UN Human Rights Council” Global Governance 2006/1. 15-20., https://doi.org/10.1163/19426720-01201003.

${ }^{20}$ Rahmani-Ocara (19. lj.) 16.

${ }^{21}$ Laura K. LANDolT - Byungwon Woo: „NGOs invite attention: From the United Nations Commission on Human Rights to the Human Rights Council" Journal of Human Rights, 2017/4. 407., https:// doi.org/10.1080/14754835.2016.1153411.

${ }^{22}$ Coline WARBICK: „From UN Commission on Human Rights to the UN Human Rights Council: One step forward or two steps sideways?" International and Comparative Law Quarterly 2006/3. 697.

${ }^{23}$ LAKATOS István: „Az ENSZ Emberi Jogok Bizottságától az Emberi Jogi Tanácsig vezető út, avagy az emberi jogok nemzetközi védelmének rövid története a második világháborút követően" in CsAPó Zsuzsanna (szerk.): Jubileumi tanulmánykötet az 1966. évi emberi jogi egyezségokmányok elfogadásának 50. évfordulójára (Budapest: Dialóg Campus-Nordex Kft., Wolters Kluwer 2019) 165180.; LAKATOS István: „Az ENSZ Emberi Jogi Tanácsa - vágyak és realitások” Fundamentum 2007/1. 87-97. 11.; LAKATOS István - ForGó Ágnes: „Az ENSZ emberi jogi rendszerének átalakítása az Emberi Jogi Tanács megalakulásának fényében: reform vagy visszalépés?" Acta Humana 2006/3-4. 120-149. 
Nehéz tárgyalások eredményeként az ENSZ Közgyülésnek (továbbiakban KGY) sikerült elfogadnia az EJT-t létrehozó 60/251. számú határozatot. ${ }^{24}$ Sajnos a nemzetközi közösség nem tudott konszenzusra jutni az ENSZ legfontosabb emberi jogi testületével kapcsolatos paraméterekben, így a három tartózkodó ország (Belorusz, Venezuela és Irán) mellett az USA, Izrael, a Marshall-szigetek és Palau a határozati javaslat ellen szavazott, amelyet így végül 2006. március 15-én százhetven támogató szavazattal fogadtak el. ${ }^{25}$

Az alábbi fontos különbségeket emelhetjük ki az EJT és jogelődje az EJB között:

- Az EJT státusza az ENSZ-en belül növekedett az EJB-hez képest, tekintettel arra, hogy míg a jogelőd az ECOSOC funkcionális bizottsága volt, addig az EJT a KGY alárendelt testülete lett.

- Az EJT-nek negyvenhét, míg az EJB-nek ötvenhárom ország volt a tagja. A tagság számának csökkenése együtt járt azok regionális csoportok közötti eloszlásának megváltozásával is, a dél országai javára.

- Az EJT tagjai két terminus után azonnal nem választhatók újra.

- Az EJT tagjait a KGY (jelenleg százkilencvenhárom tag) többsége választja meg, és nem az ECOSOC (ötvennégy tag) többsége.

- Súlyos és szisztematikus jogsértések esetén egy EJT-tag tagságát a KGY a jelenlévő és szavazó országok kétharmados többségével felfüggesztheti.

- Formális tagsági kritériumokat nem állítottak fel az EJT kapcsán sem, de a választások során figyelembe kell venni a jelöltek hozzájárulását az emberi jogok előmozdításához és védelméhez, valamint az ezzel kapcsolatos önkéntes vállalásaikat.

- Az ülésszakok száma és hossza megnőtt. Az EJB egyszer ülésezett hat héten keresztül. Ezzel szemben az EJT évente három ülésszakot tart - közte egy fö ülésszakot - minimum tízhetes időtartamban.

- Egy rendkívüli ülésszak összehívásához az EJB-vel szemben, ahol ehhez a tagok ötven százaléka kellett, az EJT esetében már a tagság egyharmada is elegendő.

- Az Általános Emberi Jogi Felülvizsgálati Mechanizmus (továbbiakban UPR) a leglátványosabb új eszköz az EJT kezében. Ez alapján minden ENSZ-tagállam emberi jogi helyzetének áttekintésére sor kerül négy és fél évenként (eredetileg négyévenként). Valamennyi megválasztott EJT-tagnak át kell esnie ezen az eljáráson a mandátuma alatt.

- A korábbi Emberi Jogi Albizottságot (Sub-Commission on the Promotion and Protection of Human Rights) a Tanácsadó Bizottság (Advisory Committee) váltotta fel.

- Új panaszmechanizmus jött létre, felváltva az egykori 1503-as eljárást.

${ }^{24}$ Az ENSZ Közgyülés 60/251-as határozata az Emberi Jogi Tanácsról, https://www2.ohchr.org/ english/bodies/hrcounciVdocs/A.RES.60.251_En.pdf.

${ }^{25}$ SPOHR (16. lj.) 176. 
4. AZ EMBERI JOGI TANÁCS EDDIGI TEVÉKENYSÉGÉNEK ÉS EGYES INTÉZMÉNYEINEK KRITIKAI VIZSGÁLATA

\subsection{TAGSÁG, REGIONÁLIS CSOPORTOK, ÖNKÉNTES VÁLLALÁSOK, RENDKÍVÜLI ÜLÉSSZAKOK, NAPIREND, TESTÜLET STÁTUSZA}

A Magasszintű Panel, amikor 2004-es jelentésében az EJB felváltását javasolta az Emberi Jogi Tanáccsal, úgy vélte, hogy az új testületnek univerzális tagsággal kell rendelkeznie, és az Alapokmány szerinti fő szervvé kell válnia az EJB korábbi ECOSOC funkcionális bizottsági státusza helyett. Az volt a célja a Panelnak, hogy elkerüljék az EJB összetételével kapcsolatos - a testület utolsó éveiben gyakran hangoztatott - kritikákat, valamint, hogy megelőzzék a tagsági kritériumokkal kapcsolatos esetleges vitákat. ${ }^{26}$ Annak ellenére, hogy Kofi Annan egyetértett a Panel értékelésével, ő egy kisebb létszámú testület mellett szállt síkra, amely legyen vagy az ENSZ fő szerve, vagy a KGY alárendelt testülete. ${ }^{27}$ Az volt az álláspontja, hogy az EJT legyen az „elkötelezettek társasága”, olyan tagokkal, amelyek láthatóan törekednek a magasabb emberi jogi standardok elérésére. A testület általa javasolt mérete inkább a Biztonsági Tanács tizenötös, mint az EJB ötvenhármas létszámához közelített volna. ${ }^{28}$ Ezt a javaslatot Washington erősen támogatta, amely szintén pozitívan viszonyult a főtitkár azon elképzeléséhez, hogy az EJT tagjait a KGY kétharmados többséggel (jelen állás szerint százhuszonnyolc támogató szavazat) válassza meg. ${ }^{29} \mathrm{Az}$ Egyesült Államok az EU-tagállamokkal együtt támogatásáról biztosította azt az elképzelést is, hogy azon országok ne lehessenek tagok, amelyek a Biztonsági Tanács Alapokmány VII. fejezete ${ }^{30}$ alá tartozó intézkedései alatt állnak emberi jogsértések vagy terrorista tevékenységek miatt. ${ }^{31}$ A testület tagságának mérete élénk vitákat generált a tagállamok között, mivel számos ország bár egyetértett azzal, hogy egy kisebb testület hatékonyabb lenne, úgy vélték, hogy az nem lenne kellően reprezentatív. ${ }^{32}$ Amint azt Conall Mallory is aláhúzta, egy szigorú tagsági kritériumrendszer az EJT-t egy alul reprezentált testületté tette volna mind földrajzi, mind a tagok vallási, politikai és kulturális hátterét illetően. ${ }^{33}$

Az univerzális tagság kérdését szintén megvizsgálták a tagállamok, annak érdekében, hogy elkerülhető legyen a testület átpolitizáltsága, de végül a tagállamok többsége azt nem támogatta. ${ }^{34}$ Ezt a megoldást sok diplomata a KGY szintén emberi jogi kérdésekkel is foglalkozó III. Bizottságának duplikációjaként értékelte volna.

${ }^{26}$ Freedman (5. lj.) 44-45.

27 SPOHR (16. lj.) 175.

28 WARBICK (22. lj.) 700.

29 Boyle (8. lj.) 30.

${ }^{30}$ ENSZ Alapokmány VII. fejezet „Eljárás a béke veszélyeztetése, a béke megszegése és támadó cselekmények esetében."

31 Conall MalloRY: „Membership and the UN Human Rights Council” Canadian Journal of Human Rights 2013/1. 22.

32 WARBICK (22. lj.) 700 .

33 Mallory (31. lj.) 10.

34 Freedman (5. lj.) 48 . 
A végső, kompromisszumos megoldás értelmében az új testület létszáma némileg kisebb lett, ötvenhárom helyett negyvenhét tag, és a jelöltek megválasztásához a KGY egyszerü többsége (jelen állás szerint kilencvenhét a százkilencvenhárom szavazatból) kell. Az arányos földrajzi elosztás elvének biztosítása érdekében a helyek többségét (huszonhatot a negyvenhétből) az Afrikai és az Ázsiai és Csendes-óceáni Csoportok kapták meg. Az Afrikai Csoport tizenhárom helyet (27,6\%) kapott a korábbi tizenöt helyett, viszont az Ázsiai és Csendes-óceáni Csoport létszáma a korábbi tizenkettőről szintén tizenháromra (27,6\%) nőtt. A WEOG befolyása csökkent, mivel a korábbi tíz hely helyett csak hetet kaptak (14,8\%). A Kelet-európai Csoport (továbbiakban EEG) egy extra helyet nyert (hatot az eddigi öt helyett, 12,7\%), míg a Latin-amerikai és Karibi Csoport (GRULAC) három helyet vesztett (nyolc helyük lett az eddigi tizenegy helyett, 17\%). Az EJT a KGY alárendelt testülete lett, ami nem igényelte az ENSZ Alapokmányának módosítását. ${ }^{35}$ Kétségtelen, hogy az emberi jogok iránt elkötelezett országok a tárgyalások során mindent megtettek annak érdekében, hogy az Emberi Jogi Tanács a Közgyüléshez, a Biztonsági Tanácshoz, a Gyámsági Tanácshoz ${ }^{36}$, a Nemzetközi Bírósághoz, a Titkársághoz vagy a Gazdasági és Szociális Tanácshoz hasonlóan a világszervezet fő szervévé váljon. A tagállamok viszont nem álltak készen arra, hogy egy adott esetben többéves szövegezési tárgyalássorozatba kezdjenek az ENSZ Alapokmány - kétharmados támogatást igénylő - módosításával kapcsolatban, mivel abban konszenzus állt fenn a kormányok körében, hogy egy ilyen folyamat keretei között egy átfogó revízióra lenne szükség. (Az Alapokmány eddigi öt módosítása leginkább csak bizonyos testületek - BT, ECOSOC - létszámának a növekedését rögzítette.) A fő szervi státusz természetesen jelentős előrelépést jelentett volna az emberi jogi diplomácia területén, hiszen ezáltal orvosolható lett volna az a tény, hogy a világszervezet alapításakor az emberi jogi kérdések nem kaptak kellő hangsúlyt az Alapokmányban. Ezen terület jelentősége azonban az elmúlt évtizedek során megnőtt és az emberi jogi kérdések minden ország külpolitikájának kiemelt részét képezik napjainkban. Gyakorlatilag már a jogelőd Emberi Jogok Bizottsága is fontosabb politikai szerepet játszott a szervezet életében és a nemzetközi kapcsolatokban, mint akár a Gyámsági Tanács vagy a Gazdasági és Szociális Tanács.

$\mathrm{Az}$ alapító határozat értelmében a jelölt országoktól elvárható, hogy az emberi jogok védelme és előmozdítása kapcsán a legmagasabb szintủ standardoknak feleljenek meg. Teljes mértékben együtt kell működniük az EJT-vel és a tagságuk során át kell menniük a UPR eljáráson. Az őket megválasztó tagállamoknak figyelembe kell venniük az emberi jogok védelméhez és előmozdításához történő hozzájárulásukat és azokat az önkéntes vállalásokat, amelyeket jelöltségük során tesznek. ${ }^{37} \mathrm{Az}$ elmúlt

${ }^{35}$ Nico ScHriver: „The UN Human Rights Council: A new »society of the committed « or just old wine in new bottles?" in T. SKouteris - A. VERMEER-KünZLI (szerk.): The Protection of the Individual in International Law. Essays in Honor of John Dugard (Cambridge, UK and NY, USA: Cambridge University Press 2007) 87., https://doi.org/10.1017/s0922156507004463.

${ }^{36}$ A Gyámsági Tanács ma már csak papíron létezik. Palau függetlenné válását követően, 1994 novemberében a testület felfüggesztette müködését.

${ }^{37}$ Bertrand G. Ramcharan: The Law, Policy and Politics of the UN Human Rights Council (Leiden, Netherlands: Brill Nijhoff 2015) 2., https://doi.org/10.1163/9789004289031. 
években egyre inkább megfigyelhető. hogy számos ország csak általános érvényü nyilatkozatokat tesz jószándékaival kapcsolatban, de van néhány olyan kormány is, amelyek már arra sem veszik a fáradságot, hogy a korábbi vállalásaikat egyáltalán frissítsék, vagy ahogy az történt első alkalommal Uganda esetében 2010-ben, még önkéntes vállalásokat sem nyújtott be a jelentkezése mellé. ${ }^{38} \mathrm{Az}$ EJT tevékenységének elején számos reménykeltő eset is történt, amikor a jelölt országok emberi jogi teljesítményével kapcsolatos elvárásoknak elrettentő hatásuk volt és például, mind Szudánt és Zimbabwét visszatartotta attól, hogy jelöltessék magukat a testületbe, vagy Irán és Belorusz végül visszavonta jelöltségét, miután érzékelték, hogy gyenge emberi jogi teljesítményük miatt nem fogják megválasztani őket. ${ }^{39}$

Azonban az emberi jogi elvárások hatástalanok azokban az esetekben, amikor nincs verseny a tagállamok között az EJT-be való bekerülés során. Ez történt az EJB esetében is, és sajnos az EJT első évét és néhány más alkalmat leszámítva a Tanács sem tudta elkerülni ezt a helyzetet. Az ún. akadálymentes jelöltlista („clean slate”) jelensége azt jelentette, hogy az adott regionális csoport pontosan annyi jelöltet állított, mint ahány helyre jogosult volt, és így a KGY-nek nem volt más lehetősége, csak hogy megválassza a jelölteket. 2006-ban valamennyi regionális csoport több jelöltet állított, mint ahány helye volt, és így hatvanöt jelölés futott be negyvenhét helyre. ${ }^{40}$ Sajnos ez a verseny a későbbiekben szinte teljesen eltűnt. 2018-ban például tizennyolc helyre pontosan tizennyolc jelölés érkezett be. ${ }^{41} \mathrm{Ez}$ a helyzet némileg javult 2019-ben, amikor tizenhét ország jelöltette magát tizennégy helyre, de az Afrikai Csoportban és a WEOG-ban így sem volt verseny. ${ }^{42} \mathrm{Az}$ ún. „clean slate” szavazás a titkossággal együtt mindenképpen rossz hatással volt az EJT-tagság összetételére, minimalizálva az önkéntes emberi jogi vállalások jelentőségét is. Számos döntés kereskedelmi, regionális vagy politikai szövetségeken, kapcsolatokon és nem az adott ország emberi jogi teljesítményén múlik. ${ }^{43}$ A clean slate helyzet megváltoztatását csak azzal lehetne elérni, ha minél több az emberi jogok ügyét prioritásként kezelő országot sikerülne meggyőzni az indulás fontosságáról. Egyes régiókban a kisebb országok nem is nagyon mernek elindulni, mert azt nagyobb és befolyásosabb szomszédaik barátságtalan diplomáciai lépésnek tekintenék. Álláspontom szerint azonban a bizonyos megtorpanásoktól eltekintve feltartóztathatatlanul zajló globális demokratizálódási folyamat középtávon változást fog hozni ezen a téren is, mivel az újdonsült demokráciák számára az EJT-tagság jelenti a legkiválóbb terepet demokratikus elkötelezettségük demonstrálására.

Mindenképpen pozitívnak volt tekinthető az a döntés, hogy egy EJT-tag két egymást követő mandátum után nem jelölhető újraválasztásra. Valamint hogy azok tagságát, akik jelentős és szisztematikus emberi jogsértéseket követnek el a mandá-

\footnotetext{
38 Mallory (31. lj.) 24-25.

39 Mallory (31. lj.) 26.

40 Mallory (31. lj.) 30.

${ }^{41}$ EJT választások, https://www.un.org/en/ga/73/meetings/elections/hrc.shtml.

${ }^{42}$ EJT választások 2019-ben, https://www.un.org/en/ga/74/meetings/elections/hrc.shtml.

43 Mallory (31. lj.) 30.
} 
tumuk során, a KGY kétharmados többséggel felfüggesztheti. ${ }^{44}$ A felfüggesztéshez szükséges magas támogatási arány ellenére 2011 márciusában az EJT úgy döntött, hogy felfüggeszti Líbia tagságát. Szimbolikus jelentőségű volt, hogy ezt a javaslatot a KGY-hez Libanon terjesztette be az OIC (Iszlám Együttmüködés Szervezete) tagjaként, az Afrikai Csoport nevében eljáró Mauritius támogatásával. ${ }^{45}$

A KGY 60/251. számú határozata értelmében az EJT évente legalább három alkalommal ülésezik, tíz héten keresztül, szemben az EJB rendelkezésére álló hat héttel. Ez a változás lehetővé teszi a globális emberi jogi kihívások hatékonyabb és átfogóbb megközelítését. ${ }^{46}$ Ezenkívül a rendkívüli ülésszakokkal kapcsolatos új szabályok szintén segítenek az EJT-nek, hogy jobban tudja kezelni a rendkívüli emberi jogi helyzeteket, amennyiben ezekkel a rendelkezéseknek megfelelően élnek. Ezek a változások mindenképpen pozitívan befolyásolták a WEOG álláspontját az EJT támogatását illetően, ellensúlyozva azt a tényt, hogy az arányuk a Tanácsban az EJB-hez képest csökkent. ${ }^{47}$

Annak hatása, hogy a rendkívüli ülésszakok összehívásának feltételei könnyebbé váltak, nagyon jelentős volt, mivel a 2006-2021-es időszak alatt harminckét rendkívüli ülésszakra került sor. Az elejétől nyilvánvalóvá vált, hogy az OIC arra használta fel ezt az eszközt, hogy nyomás alatt tartsa Izraelt, tekintettel arra, hogy kilenc ülésszak foglalkozott a megszállt palesztin területek emberi jogi helyzetével. Ezt követte a gyakoriság szempontjából a szíriai válság, amely öt ülésszaknak volt a tárgya. A mianmari/burmai emberi jogi helyzettel három rendkívüli ülésszak foglalkozott. A többi rendkívüli ülésszak témái az alábbiak voltak: Dél- Szudán, Szudán, Burundi, Afganisztán, Boko Haram, Iszlám Állam, Közép-afrikai Köztársaság, Líbia, Elefántcsontpart, Haiti, Srí Lanka, globális gazdasági és pénzügyi válságok, a Kongói Demokratikus Köztársaság, a világ élelmezési helyzete és Darfur. ${ }^{48}$

$\mathrm{Az}$ EJT napirendjén ${ }^{49}$ tíz napirendi pont szerepelt, szemben az EJB huszonegy napirendi pontjával. Egy napirendi pont azonban változatlan maradt. Az EJB 8-as napirendi pontja Az emberi jogsértésekről a megszállt arab területeken, ideértve Palesztinát is, az EJT 7-es napirendi pontjává vált A palesztin és egyéb megszállt arab területek emberi jogi helyzete címmel. Sajnálatos módon a tárgyalások során az EJT többsége úgy döntött, hogy megtartja ezt a speciális és diszkriminatív napirendi pontot egy ország emberi jogi helyzetével kapcsolatban, míg az összes többi országhelyzetet a 4-es napirendi pont alatt kezelte a Tanács.

${ }^{44}$ Veronique Joosten: The UN Human Rights Council at Work: From High Hopes Back to Reality (United Nations Association: Flanders Belgium 2011) 6., http://www.vvn.be/wp-content/uploads/ 2011/04/VVN_HRC_at_work_-_Definitieve_versie.pdf.

45 Mallory (31. lj.) 21.

46 Jarvia MaITyA: „Repositioning the International Human Rights Protection System: The UN human Rights Council" Commonwealth Law Bulletin 2010. 36/2. 318., https://doi.org/10.1080/0305071 8.2010.481399.

47 Eric Cox: „State Interests and the creation and functioning of the United Nations Human Rights Council” Journal of International Law and International Relations 2010/1. 105.

${ }^{48}$ Az ENSZ Emberi Jogi Tanács rendkívüli ülésszakai, https://www.ohchr.org/EN/HRBodies/HRC/ SpecialSessions/Pages/SpecialSessions.aspx.

${ }^{49}$ Az ENSZ Emberi Jogi Tanács napirendje https://www2.ohchr.org/english/bodies/hrcounciVdocs /10session/ProuAgenda10session.pdf. 


\subsection{SPECIÁLIS ELJÁRÁSOK}

Az EJT ún. speciális eljárásai alatt olyan független emberi jogi szakértőket értünk, akik mandátumuk alapján jelentéseket készítenek és tanácsokat adnak tematikus vagy országspecifikus emberi jogi kérdésekben. Kofi Annan ENSZ-főtitkár a speciális eljárásokat az ENSZ emberi jogi rendszere koronaékszereinek nevezte, ${ }^{50}$ amely megfelelő módon jelzi azt a fontos szerepet, amit betöltenek az emberi jogok nemzetközi védelmében és előmozdításában. Az EJB tevékenységének végeztével (2006 júniusa) huszonnyolc tematikus és tizenhárom országspecifikus mandátum létezett. Az EJT munkájának paramétereivel kapcsolatos tárgyalások során nyilvánvalóvá vált, hogy egyes országok szívesen használnák fel a UPR létrehozását arra, hogy megszabaduljanak az országspecifikus határozatoktól és mandátumoktól. Kína az országhatározatokat az „EJB krónikus betegségeinek nevezte”. ${ }^{51}$ Mindezek alapján nem volt meglepő, hogy Peking kétharmados többséget szeretett volna bevezetni az országhatározatok elfogadásához az EJT felállításakor. Végül kompromisszumos megoldás született, amely értelmében az országhatározatok beterjesztőinek a lehető legszélesebb támogatást kell biztosítaniuk a kezdeményezésükhöz - lehetőség szerint legalább tizenöt tagot - mielőtt a határozati javaslatról szavazásra kerülne sor. ${ }^{52} \mathrm{Az}$ EU és a többi - az országspecifikus határozatokat támogató - ország szerencsés volt, hogy a kínai kezdeményezés az arab országok életét is megnehezítette volna a megszállt arab területekkel kapcsolatos határozataik terén, és ez segített a kompromisszumos megoldás elfogadásában. Végül két országspecifikus mandátum, a kubai és a belorusz áldozatává vált az országhelyzetekkel kapcsolatos tagállami vitának. Ebben az átmeneti időszakban ezeket megszüntették, és ezzel folytatódott az országhelyzetekkel kapcsolatos mandátumok csökkenésének trendje (1998 és 2006 között a számuk huszonhatról tizenháromra csökkent). ${ }^{53}$

Az EJT 5/1-es számú intézményfejlesztési határozata, ${ }^{54}$ amelyet 2007. június 18-án fogadtak el, egy merev, de átláthatóbb rendszerét alakította ki a mandátumbetöltők kiválasztásának. A meghatározó szerepet az ötfős Konzultatív Csoport kapta, amelyben mindegyik regionális csoport képviselteti magát. Ez a csoport nézi át a jelentkezéseket, és beszélget el a legjobb jelöltekkel, majd ezek alapján teszi meg ajánlásait az EJT elnökének, ${ }^{55}$ aki normális esetben elfogadja a Konzultatív Csoport ajánlásait. Dönthet természetesen másként is, de ebben az esetben részletes és jól megalapozott magyarázattal kell indokolnia eltérő álláspontját. Végezetül az EJT plenáris ülésen hagyja jóvá a jelölteket, ${ }^{56}$ ami az EJB esetében nem így történt, ott

${ }^{50}$ Freedman (5. lj.) 110.

51 Joosten (44. lj.) 17.

52 Joosten (44. lj.) 17-18.

${ }^{53}$ SPOHR (16. lj.) 186.

${ }^{54}$ Az EJT 5/1-es határozata az ENSZ Emberi Jogi Tanács intézményépítéséről, http://hrlibrary.umn. edw/iwraw/Inst-building-UN.pdf.

${ }^{55}$ Christian Tomuschat: „Origins and history of UN special procedures. An overview from their inception to June 2007” Human Rights Law Journal 2007/1-5. 30.

${ }^{56}$ Alapvető információk az EJT független szakértőinek kiválasztásáról és kinevezéséről, $h t t p s: / / w w w$. ohchr.org/EN/HRBodies/HRC/SP/Pages/BasicInformationSelectionIndependentExperts.aspx. 
ugyanis az elnök a Büróval ${ }^{57}$ való konzultációt követően, de egyszemélyben hozta meg a döntést, amely azt követően már nem igényelte a plenáris ülés jóváhagyását. ${ }^{58}$ Fontos megjegyeznünk, hogy az országok mellett regionális csoportok, nemzetközi szervezetek és NGO-k is javasolhatnak jelölteket, amelyeket ezt követően a Konzultatív Csoport áttekint. ${ }^{59} \mathrm{Az}$ országspecifikus mandátumokat évente, a tematikusokat háromévente kell meghosszabbítani. E szabály alól egy kivétel van. A megszállt arab területek emberi jogi helyzetével foglalkozó mandátum, amely addig tart, „ameddig ezen területek izraeli megszállása nem ér véget”, és ennek értelmében azt nem kell évente megújítani a többi országspecifikus mandátumhoz hasonlóan. ${ }^{60}$

A mandátumbetöltők munkájával kapcsolatban egyes országok által megfogalmazott éles kritikákra válaszul egy nem túl szerencsés határozatot fogadott el az EJT 2007 júniusában a Különleges Eljárások mandátumainak betöltőire vonatkozó Magatartási Szabályzatról (5/2-es számú EJT határozat), ${ }^{61}$, amelynek az volt a be nem vallott - célja, hogy a különmegbízottak működési szabadságát csökkentse. A Magatartási Szabályzat értelmében a különmegbízottaknak elsőbbséget kell adniuk a kormányoktól érkező információknak. A Szabályzat sajnos alkalmas eszköz lehet a civil hangok elhallgattatására és a kormányzati narratívák felerősítésére, ami a különmegbízottak munkájának pártatlanságát veszélyezteti, csökkentve annak kritikai élét.

2021 decemberében negyvenöt tematikus ${ }^{62}$ és tizenhárom országspecifikus ${ }^{63}$ mandátum működött. Az EJT tizennégy év alatt létrehozott tizenhét új tematikus mandátumot, míg az országspecifikus mandátumok száma nem változott az EJT 2006os életre hívásának időpontjához képes. ${ }^{64}$ Ahogy azt Marc Limon is megállapította, amennyiben ez a tendencia folytatódik, 2030-ra a mandátumok száma el fogja érni

${ }^{57}$ A Bürónak az EJB és az EJT esetében is az elnök mellett a három alelnök és a rapportőr a tagja.

${ }^{58}$ Manfred NowAK - Moritz BIRK - Tiphanie CRITTIN - Kozma Júlia: „UN Human Rights Council in Crisis - proposals to enhance the effectiveness of the Council” in Wolfgang BENEDEK - Florennce Benoit-Rohmer - Wolfram KaRL - Manfred NowaK (szerk.): European Yearbook on Human Rights (Cambridge, UK: Intersentia Ltd. 2011) 67.

59 Joosten (44. lj.) 26.

60 Joosten (44. lj.) 24.

${ }^{61}$ HRC Resolution 5/2. On Code of Conduct for Special Procedures Mandate-holders of the Human Rights Council, https://www.ohchr.org/Documents/HRBodies/SP/CodeOfConduct.pdf.

${ }^{62}$ Az EJT tematikus speciális eljárásai az alábbi kérdéseket érintik: afrikai származású emberek, albinizmus, önkényes fogva tartás, üzleti és emberi jogok, kulturális jogok, fejlődés, fogyatékossággal élők jogai, eltűnések, oktatás, környezet, kivégzések, élelem, külföldi adósság, véleményszabadság, békés gyülekezés és egyesülés joga, veszélyes anyagok, egészség, lakhatás, emberi jogvédők, bírói függetlenség, őslakosok, belső migrációra kényszerített emberek, nemzetközi rend, nemzetközi szolidaritás, lepra, zsoldosok, migránsok, kisebbségi kérdések, idősek, szegénység, privát szféra, raszszizmus, vallás, meggyőződés, gyermekkereskedelem, szexuális orientáció és nemi identitás, rabszolgaság, terrorizmus, kínzás, emberkereskedelem, igazság, egyoldalú kényszerítő intézkedések, nők elleni erőszak, víz és egészségügyi viszonyok, nők, lányok, valamint az utolsóként létrehozott mandátum a klímaváltozás emberi jogi hatásaival kapcsolatban.

${ }^{63}$ Az EJT országspecifikus eljárásai: Afganisztán, Belorusz, Kambodzsa, Közép-afrikai Köztársaság, Észak-Korea, Eritrea, Irán, Mali, Mianmar, az 1967 óta elfoglalt palesztin területek, Szomália, Szudán, Szíria.

${ }^{64}$ Az Emberi Jogi Tanács speciális eljárásai, www.ohchr.org/en/hrbodies/sp/pages/welcomepage. aspx. 
a százat. ${ }^{65} \mathrm{Ez}$ a trend nem meglepő, tekintettel arra, hogy egy mandátum létrehozatala mindig nehezebb, mint az időszakos megújítása, ${ }^{66}$ és arra nagyon kevés példa volt, hogy valamelyik mandátumot megszüntették volna.

Ezt a jelenséget egy érdekes kutatással mutatta be Rosa Freedman és Jacob Mchangama a speciális eljárások elszaporodása kapcsán. Tanulmányuk kimutatta, hogy a Freedom House terminológiái szerinti ún. szabad államok mindig készségesebben támogatják a polgári és politikai jogokkal kapcsolatos mandátumok életre hívását, míg ez a támogatás már közel sem olyan egyértelmű a gazdasági és szociális jogokkal kapcsolatos mandátumok esetében. Ezen országok meglehetősen szkeptikusak az ún. harmadik generációs jogok tekintetében, amelyeket leginkább az ún. nem szabad államok támogatják, amelyek viszont ritkán állnak a polgári és politikai jogokkal foglalkozó mandátumok mögé ${ }^{67}$ Kutatásuk egyik fontos megállapítása az volt, hogy általában a részben szabad és nem szabad államok, amelyek gyengébb emberi jogi teljesítménnyel rendelkeznek, támogatják a mandátumok proliferációját, tágítva a polgári és politikai jogi mandátumok szűkebb fókuszát, a gazdasági, szociális és harmadik generációs jogokkal foglalkozó drágább mandátumokra helyezve a hangsúlyt. ${ }^{68}$ Kutatási eredményeik azt mutatják, hogy a speciális eljárásoknak már nemcsak az emberi jogok előmozdítása és védelme a céljuk, hanem azok egy fontos eszközzé váltak a tagállamok közötti ideológiai és politikai harcban, ahol a tagállamok a saját napirendjüket követik a céljaik megvalósítása érdekében. ${ }^{69}$ Nehéz kikezdeni Freedman és Mchangama végső értékelését azzal kapcsolatban, hogy a mandátumok számának növelése megfelelő pénzügyi háttér hiányában mindenképpen negatív hatással lesz az egész speciális eljárási rendszerre nézve. Mindenképpen beszédes adatnak tekinthető, hogy az OHCHR 2012-es pénzügyi beszámolója értelmében a célzott támogatásoknak csak $24 \%$-át ${ }^{70}$ fordították polgári és politikai jogi mandátumokra, míg a gazdasági, szociális és kulturális jogi területek 44\%-ot kaptak, valamint a fókuszban lévő csoportokkal (pl. kisebbségek, őslakosok, fogyatékosággal élők, nők, gyermekek) kapcsolatos kezdeményezések a pénzek 32\%-t kapták meg. Álláspontom szerint jelenleg számos olyan tematikus mandátum létezik, amelyek gyakorlati, kézzel fogható eredményeket nem hoznak a nemzetközi emberi jogi rendszerbe, viszont jelentős anyagi erőforrások lekötésével nehezítik a fontos és hatékony mechanizmusok munkáját. Ilyen mandátumnak tekinthetők többek között a külföldi adóssággal, a veszélyes anyagokkal, a nemzetközi renddel, a nemzetközi szolidaritással vagy az egyoldalú kényszerítő intézkedésekkel foglalkozó mechanizmusok, amelyek inkább politikai, mint emberi jogi célokat szolgálnak.

1994 óta a különböző EJT-mandátumok betöltői évente találkoznak Genfben. Ezek a találkozók remek alkalmat jelentenek arra, hogy a szakértők tájékozódjanak a jó

${ }^{65}$ Rosa Freedman - Jacob McHahgama: „Expanding or diluting human rights? The proliferation of United Nations Special Procedures Mandates" Human Rights Quarterly 2016/1. 165., https://doi. org/10.1353/hrq.2016.0012.

${ }^{66}$ Freedman-McHangama (65. lj.)173.

67 Freedman-McHangama (65. lj.) 180-181.

${ }^{68}$ Freedman-McHangama (65. lj.) 187.

${ }^{69}$ Freedman-McHangama (65. lj.) 190.

${ }^{70}$ Freedman-McHangama (65. lj.)193. 
gyakorlatokkal kapcsolatban, és harmonizálni tudják a különböző munkamódszereiket. Az EJT-hez benyújtott éves jelentésük tartalmazza a legfontosabb adatokat a különleges eljárások rendszerével kapcsolatban. A 2018-as jelentés értelmében a rendszerben akkor nyolcvan mandátum szerepelt, amelyek 45\%-át nők, míg 55\%át férfiak töltötték be. ${ }^{71} \mathrm{~A}$ jelentés fontos adatokat tartalmazott a speciális eljárásokkal történő együttmüködéssel kapcsolatban is. Ennek értelmében a tagállamok túlnyomó többsége, nevezetesen 169 ország fogadott már legalább egy mandátumbetöltőt. Azonban huszonnégy országot még egyetlen mandátumbetöltő sem látogatott meg, és ezek közül hét még soha felkérést sem kapott ilyen látogatásra, míg tizennégy még egyet sem fogadott el, és három olyan ország van, amelyik már beleegyezett egy látogatásba, de arra még nem került sor. ${ }^{72}$ Ebben a kontextusban meg kell említenünk az ún. állandó meghívás (standing invitation) intézményét. Ez nyílt meghívást jelent a kormány részéröl, valamennyi tematikus mandátum irányában. Egy ilyen állandó meghívó kibocsátásával a kormány kijelenti, hogy kész eleget tenni bármelyik speciális eljárás meghívási kérésének. A 2021. decemberi állapot szerint százhuszonnyolc tagállam és egy megfigyelő tett ilyen jellegű nyilatkozatot. ${ }^{73}$

\section{3. ÁLTALÁNOS EMBERI JOGI FELÜLVIZSGÁLATI \\ MECHANIZMUS (UNIVERSAL PERIODIC REVIEW - UPR)}

A UPR az egyetlen olyan univerzális eljárás, amely magában foglalja valamennyi ENSZ-tagállam emberi jogi helyzetének áttekintését. (A mechanizmussal hazánkban Komanovics Adrienne foglalkozott több cikkében is.) ${ }^{74}$ A UPR-folyamatot a tagállamok működtetik az EJT keretei között, minden országnak lehetőséget biztosítva, hogy beszámoljanak azokról a lépésekről, amelyeket az országuk emberi jogi helyzetének érdekében tettek, és abból a célból, hogy eleget tegyenek emberi jogi kötelezettségeiknek. A UPR-t azzal a céllal hozták létre, hogy valamennyi ország számára egyenlő elbánást biztosítson az emberi jogi helyzetének felmérése során. A folyamat legfontosabb célja természetesen, hogy valamennyi országban javítsa az

71 A/HRC/40/38, Report on the twenty-fifth annual meeting of Special Rapporteurs/representatives, independent experts and chairs of working groups of the special procedures of the Human Rights Council (Geneva, 4 to 8 June 2018), including updated information on special procedures, 3.

72 A/HRC/40/38 (71. lj.) 3.

73 Standing Invitations to thematic special procedures, https://spinternet.ohchr.org/ StandingInvitations.aspx?lang=en.

74 Komanovics Adrienne: „The Human Rights Council and the Universal Periodic Review: Is it more than a public relations exercise?" in Zsolt György BALOGH (szerk.): Essays of Faculty of Law University of Pécs: Yearbook of 2012 (Pécs: University of Pécs Faculty of Law 2012) 119-146.; Komanovics Adrienne: „The Human Rights Council and the Universal Periodic Review: A novel method of promoting compliance with human rights" in Drinóczi Tímea - Mirela Zupan - Ercsey Zsombor - Mario Vinkovic (szerk.): Contemporary legal challenges: EU - Hungary - Croatia (Pécs - Osijek: University of Pécs Faculty of Law, Josip Juraj Strossmayer University of Osijek, Faculty of Law 2012) 641-669.; Komanovics Adrienne: „Kereszttűzben Genfben: Magyarország emberi jogi helyzetének értékelése az ENSZ Emberi Jogi Tanácsában” Föld-Rész: Nemzetközi és Európai Jogi Szemle 2011/2-4. 7-27. 
emberi jogi helyzetet, és foglalkozzon az emberi jogsértésekkel, bárhol forduljanak is azok elő. ${ }^{75}$

A UPR életre hívását valamennyi megfigyelő az EJT leglátványosabb új intézményének tekintette, amely a konstruktív párbeszéd és együttmüködés koncepcióján alapul, és amely jelentős elmozdulást jelentett sok fejlődő ország szemében a korábbi EJB által követett „megnevezni és megszégyeníteni” („naming and shaming”) megközelítéstöl. Sok ország azt remélte, hogy a UPR a sok vihart kavaró országhatározatok és mandátumok alternatíváját fogja jelenteni. ${ }^{76}$ Ahogy azonban azt Hollandia is kiemelte a UPR-felülvizsgálat során: „A UPR egy addicionális eszközt jelent az emberi jogok ellenőrzése során, amely kiegészíti és nem duplikálja a treaty body- $\mathrm{k}^{77}$ és a speciális eljárások munkáját. Továbbá a felülvizsgálat nem változtathatja meg az EJT mandátumát, hogy reagáljon az egyes országokban történő súlyos emberi jogsértésekre."78

A UPR fontos hozzáadott értékét jelenti a kooperatív atmoszféra megteremtése, amelyben az országok előmozdíthatnak olyan közös emberi jogi cselekvési programokat, amelyek a jó gyakorlatok megosztása révén a helyszíni emberi jogi helyzet javítását célozzák. ${ }^{79}$ A UPR fontos jellemzője, hogy könnyen összekapcsolható technikai segítségnyújtási, kapacitásnövelő programokkal, elősegítve a UPR-ajánlások hatékonyabb végrehajtását. Az ún. Voluntary Fund for Financial and Technical Assistance (Önkéntes Pénzügyi és Technikai Segítségnyújtási Alap) létrehozatala éppen ezt a célt szolgálja. ${ }^{80}$

Néhány szakértő és akadémiai ember aggodalmát fejezte ki azonban, hogy a UPR rituálévá fog válni, amelyben a puszta részvétel már nem jár együtt azzal a szándékkal, hogy az emberi jogok helyzetében a helyszínen érjünk el érdemi változásokat. ${ }^{81}$ A kormányközi folyamat kooperatív és nem konfrontációs jellege - amely nem tartalmaz büntető szankciókat sem - volt az ára bizonyos fejlődő országok támogatásának, annak ellenére, hogy az 5/1-es EJT-határozat nyilvánvalóvá teszi, hogy a UPR „nem csökkentheti a Tanács azon kapacitását, hogy válaszolni tudjon sürgős emberi jogi helyzetekre". ${ }^{82}$ Ebben a tekintetben fontos, hogy a megszokás megfele-

${ }^{75}$ UPR, https://www.ohchr.org/en/hrbodies/upr/pages/uprmain.aspx.

76 Joosten (44. lj.) 32.

77 Az ENSZ emberei jogi egyezmények végrehajtásán őrködő testületek, amelyeknek független szakértők a tagjai, és amelyek megtárgyalják az adott egyezmény részes államai által az egyezmény végrehajtásáról időszakosan beszámoló jelentéseket.

78 John CAREY: „The UN Human Rights Council: What would Eleanor Roosevelt say?” ILSA Journal of International and Comparative Law 2009/1. 469.

${ }^{79}$ Constanca de la VEgA - Tamara N. Lewis: „Peer review in the mix: How the UPR transforms humanrights discourse" in M. Cherif BAssiouni - William. A. Schabas (szerk.): New Challenges for the UN Human Rights Machinery (Cambridge, UK: Intersentia Ltd. 2011) 385.

${ }^{80}$ Hilary Charlesworth - Emma LARKInG: „Introduction:the regulatory power of the Universal Periodic Review" in Hilary Charlesworth - Emma Larking (szerk.): Human Rights and the Universal Periodic Review. Rituals and Ritualism (Cambridge, UK: Cambridge University Press 2014) 6-7.

${ }^{81}$ Charlesworth-Larking (80. lj.) 10.

${ }^{82}$ Edward McMahon - Marta Ascherio: „A step ahead in promoting human rights? The Universal Periodic Review of the UN Human Rights Council” Global Governance 2012/2. 234. 
léssé vagy elkötelezettséggé alakuljon át. „Nem szabad megengedni, hogy az államok el tudják fedni az emberi jogok iránti alacsony elköteleződésüket a folyamatban való puszta részvétellel." 83

A UPR-folyamatban megvan az a lehetőség, hogy kialakítson egy, az eddigieknél inkluzívabb, nemzetközi emberi jogi agendát és az Emberi Jogok Egyetemes Nyilatkozatára való hivatkozással az érintett emberi jogok átfogó listája jön létre. Ez különösen fontos olyan régiókban, ahol a nemzetközi emberi jogi egyezmények ratifikációjának szintje alacsony. A világ periférikus régiói ezáltal részt tudnak venni egy közös emberi jogi párbeszédben. ${ }^{84}$ A UPR hangsúlyozza a bilaterális, stateto-state kapcsolatokat, amely újdonságot jelent az EJT más szektorainak munkájához képest, amelyekre a regionalitás, és az Észak-Dél megosztottság jellemző. ${ }^{85}$ Edward McMahon és Marta Ascherio kutatásai bemutatják, hogy az Afrikai és az Ázsiai-Csendes-óceáni Csoportok az ajánlásaik 40\%-át a saját régiójuk országai irányában fogalmazták meg, míg ez az arány sokkal kisebb a másik három regionális csoport (EEG, GRULAC és WEOG) esetében. ${ }^{86}$ A fent jelzett jelenséggel összhangban a korábban jelzett két regionális csoport országai sokkal nyitottabbak voltak a saját régiójukból érkező ajánlások elfogadására. ${ }^{87}$ Következtetésképpen nyilvánvaló regionális sajátosságokat találhatunk a folyamat során, amelyek értelmében az ázsiai és afrikai országok esetében sokkal gyengédebb megközelítést találunk az emberi jogi kérdések tekintetében, míg a WEOG országai fogalmazzák meg a legkritikusabb, konkrét lépéseket igénylő ajánlásokat. A GRULAC és az EEG egyfajta közvetítő szerepet játszhat az afrikai/ázsiai országok és a Nyugat-európai és Egyéb Országok Csoportja között a történelmi hátterük okán. McMahon és Ascherio fontos megállapítása az volt, hogy az EJT hosszú távú sikeressége azon múlik, hogy vajon az államok felismerik-e, hogy a kritika az együttmüködésfontos eleme lehet. ${ }^{88}$

\subsection{PANASZELJÁRÁS ${ }^{89}$}

Tekintettel arra, hogy a tagállamok nem mutattak túl sok érdeklődést az EJB korábbi, ún. 1503-as eljárásának megreformálása iránt, az kisebb változtatásokkal, de tovább folytatódott ${ }^{90}$-az elfogadhatósági feltételek könnyebbé válásával, valamint az eseteket vizsgáló bizottságok ülései gyakoriságának növelésével. A panaszeljá-

${ }^{83}$ Charlesworth-Larking (80. lj.) 12.

${ }^{84}$ Charlesworth-Larking (80. lj.) 13.

${ }^{85}$ McMaharon-Ascherio (82. lj.) 234-235.

${ }^{86}$ McMaharon-Ascherio (82. lj.) 237.

${ }^{87}$ McMaharon-Ascherio (82. lj.) 242.

${ }^{88}$ McMaharon-Ascherio (82. lj.) 246.

${ }^{89}$ Human Rights Council Complaint Procedure https://www.ohchr.org/en/hrbodies/hrc/ complaintprocedure/pages/hrccomplaintprocedureindex.aspx.

${ }^{90}$ Maximilian SpoнR: „United Nations Human Rights Council. Between institution-building phase and review of status" in Armin von Bogdandy - Rüdiger Wolfrum (szerk.): Max Planck Yearbook of United Nations Law (Heidelberg: Max Planck Institute 2010) 169-218. 
rás célja az volt, hogy foglalkozzon bármely körülmények között, a világ bármely részén bekövetkező olyan súlyos emberi jogsértésekkel, amelyek egy következetes mintázatot mutatnak, valamint bizonyíthatók. A fő különbséget a „bármely körülmények között” kitétel jelenti, amely csökkenti annak lehetőségét, hogy valaki akár tartalmi, akár földrajzi hatály okán megkérdőjelezné az eljárást. Ez alapján a vészhelyzet vagy belső konfliktus sem akadályozza meg az EJT-t az adott helyzet vizsgálatában. Az elfogadhatósági feltételek szintén megváltoztak, nem zárva ki például azon esetet, amikor az adott ország az EJT nyilvános eljárása alatt is áll, vagy ha a panasz valamelyik speciális eljárás mandátuma alá esik. Most egyedül a litis pendentia ${ }^{91}$ zárja ki egy új panasz elfogadhatóságát.

\subsection{NEM KORMÁNYZATI SZERVEZETEK ÉS NEMZETI EMBERI JOGI INTÉZMÉNYEK RÉSZVÉTELE AZ EMBERI JOGI TANÁCS MUNKÁJÁBAN}

Az NGO-k részvételét illetően az EJB rendelkezett a legliberálisabb szabályozással az ENSZ egész rendszerén belül. Az ECOSOC által akkreditált NGO-k részt vehettek valamennyi nyilvános ülésen, és felszólalhattak a különböző napirendi pontok alatt. Ezenkívül írásos anyagokat is köröztethettek a tagállamok körében. ${ }^{92}$ Ezeket a jogokat csak azon NGO-k élvezhették, amelyek konzultatív státuszát az ún. NGO Bizottság állapította meg, amely egy New Yorkban ülésező, tizenkilenc tagállam képviselőiből álló testület. A konzultatív státusz feltételeit az ECOSOC 1996/31-es határozata szabályozta. ${ }^{93}$ Jelenleg több mint háromezer NGO rendelkezik konzultatív státusszal az ECOSOC-nál. ${ }^{94} \mathrm{Az}$ EJT alapító határozata értelmében az NGO-k és a nemzeti emberi jogi intézmények (NHRI) ${ }^{95}$ részvétele az EJB-modellt követi, és ezek a szabályok alkalmazandók az EJT esetében is. ${ }^{96}$

Laura K. Landolt és Byungwon Woo kutatása az NGO-k EJB és EJT munkájában való részvételével kapcsolatban megállapította, hogy az EJT megalakításának láthatóan pozitív hatása volt a helyi és regionális NGO-k részvételére. Munkájuk azt támasztotta alá, hogy a demokratikusabb és EJB/EJT-tagországok emberi jogi helyzetére vonatkozóan több NGO felszólalás születik. ${ }^{97}$ Nyilvánvaló a statisztikai

91 Litis pendentia: A polgári per elutasításának indokaként a függőségi jogvesztés olyan helyzetre utal, amikor ugyanazon felek között ugyanazon jogalap miatt két per van folyamatban, így az egyik feleslegessé válik.

${ }^{92}$ Meghna Abraham: A New Chapter for Human Rights. A Handbook on issues of transition from the Commission on Human Rights to the Human Rights Council (International Service for Human Rights, Friedrich Ebert Stiftiung 2016) 88.

93 Julie A. Mertus: The United Nations and Human Rights. A Guide for a New Era (Abingdon, UK: Routledge $\left.{ }^{2} 2009\right) 62$.

${ }^{94}$ NGO Branch of UN Department of Economic and Social Affairs, https://esango.un.org/paperless/ Web? page $=$ static\& content $=$ faqs.

${ }^{95}$ A nemzeti emberi jogi intézmények közé tartoznak az ombudsmani hivatalok és egyes nemzeti emberi jogi bizottságok.

96 ABRAHAM (92. lj.) 91.

${ }^{97}$ Landolt-Woo (21. lj.) 420. 
adatokból, hogy az EJT által hozott eljárási újítások megnövelték az NGO-k részvételét, különös tekintettel a Globális Dél NGO-ira. ${ }^{98}$

Olivier de Frouville kiemelte azonban, hogy mivel az EJT évente három ülésszakot tart, valamint három UPR-ülésszakra is sor kerül, nem beszélve a számos rendkívüli ülésszakról, az NGO-k számára különösen nehézzé vált az összes esemény figyelemmel kísérése. A pénzügyi nehézségek mellett egyre nyilvánvalóbb az ún. kormányok által megszervezett és pénzelt NGO-k (GONGO-k) jelensége, valamint azok a különböző formákat öltő intézkedések, amelyek korlátozni kívánják az NGO-k munkáját az EJT-ben. ${ }^{99}$ Az EJT 24/24-es - hazánk által beterjesztett - határozata az ENSZ-szel való emberi jogi együttmüködésről („Cooperation with the United Nations, its representatives and mechanisms in the field of human rights") kezdeményezte egy ún. ENSZ-es focal point (koordinátor) kinevezését, akinek az a feladata, hogy megtegyen mindent annak érdekében, hogy a világszervezettel emberi jogi kérdésekben együttműködő személyeket a kormányok vagy más szereplök részéről ne érje megtorlás. Ezenkívül az ENSZ egész rendszerén belül az ilyen esetekre válaszul azonnali és egységes válaszok szülessenek. ${ }^{100}$ A határozat eredményeként az ENSZ-főtitkár 2016 októberében kinevezte Andrew Gilmour emberi jogi főtitkárhelyettest a fent jelzett problémák kezelésére. ${ }^{101} \mathrm{~A}$ határozat által kezdeményezett mechanizmusnak döntő jelentősége lehet az ENSZ hitelességének megőrzésében, hiszen a világszervezettel együttmüködők megfélemlítése vagy elhallgattatása az egész szervezet morális alapjait ásná alá.

\section{AZ EJT MUNKÁJÁVAL KAPCSOLATOS ELSŐ FELÜLVIZSGÁLAT EREDMÉNYEI, VALAMIT JÖVŐBELI KIHÍVÁSOK AZ ENSZ KÖZGYÜLÉS ÁLTALI KÖZELJÖVŐBEN SORRA KERÜLÖ EJT-FELÜLVIZSGÁLAT FÉNYÉBEN}

A 60/251-es határozat öt évvel a felállítását követően rendelkezett az EJT munkájával kapcsolatos felülvizsgálatról, melynek két eleme volt. Az első keretében az EJT intézményi státuszáról kellett dönteni, a második során pedig az új emberi jogi testület funkcióit kellett áttekinteni. Ennek megfelelően 2009-ben az EJT felállított egy Kormányközi Munkacsoportot (Open-Ended Intergovernmental Working

${ }^{98}$ LANDolt-Woo (21. lj.) 421.

${ }^{99}$ Olivierde Frouville: „Building a universal system for the protection of human rights: The way forward" in M. Cherif Bassiouni - William A. Schabas (szerk.): New Challenges for the UN Human Rights Machinery (Cambridge, UK: Intersentia Ltd. 2011) 249.

${ }^{100}$ HRC Resolution 24/24 entitled „Cooperation with the United Nations, its representatives and mechanisms in the field of human rights", https://www.ohchr.org/EN/Issues/SRHRDefenders/Pages/ Resolutions.aspx.

${ }^{101}$ Madeleine SinclaIR - Tess McEvoy: „Ending reprisals against those who cooperate with the UN in the field of human rights. Submission to the UN Secretary-General on recent developments, cases and recommendations" International Service for Human Rights 2018. 2., https://www.ishr.ch/sites/ default/files/documents/final_for_web_ishr_submission_to_sg_reprisals_report_06_05_2018_0. $p d f$. 
Group) az EJT saját munkájának áttekintése céljából. ${ }^{102}$ Hosszú tárgyalásokat követően 2011-ben az EJT végül elfogadta a 16/21-es határozatát az Emberi Jogi Tanács Munkájának és működésének felülvizsgálatáról. ${ }^{103}$

A felülvizsgálat idején hozott döntések alapján nyilvánvaló, hogy az EJT az intézményeit vagy a munkamódszereit illetően nem volt képes radikális változásokat kieszközölni. A változások többsége inkább technikai jellegű volt, de nyilvánvalóan könnyebbé és praktikusabbá tették az EJT müködését.

Az EJT döntéseit követően az ENSZ Közgyülés 2011. június 17-én elfogadta a 65/281-es határozatát az EJT felülvizsgálatáról. ${ }^{104}$ Ebben a KGY amellett, hogy tudomásul vette az EJT 2011. március 25-i, 16/21-os számú határozatát az Emberi Jogi Tanács munkájának felülvizsgálatáról, elhatározta, hogy nem változtat az EJT státuszán, és az továbbra is a KGY alárendelt szerve marad, de nem hamarabb, mint tíz, és nem később, mint tizenöt év múlva újra napirendre tűzi ezt a kérdést, vagyis a felülvizsgálatra a 2021-26 közötti időszakban kell sort keríteni. A KGY úgy döntött, hogy az EJT éves jelentését a KGY plenáris ülése, valamint a III. Bizottság az „Emberi Jogi Tanács jelentése” címet viselő napirendi pont alatt fogja megvitatni. A határozat értelmében az EJT elnöke mutatja be a jelentést az ENSZ KGY és a III. Bizottság plenáris ülésén, és a III. Bizottság egy interaktív vitát tart az EJT elnökével a jelentésröl ekkor.

2019 májusában az ún. Glion Human Rights Dialogue ${ }^{105}$ során a résztvevők érintették az EJT jövőjével kapcsolatos kérdéseket, figyelemmel az EJT munkájának 2021 és 2026 között esedékes felülvizsgálatára. A résztvevők néhány olyan kérdést azonosítottak, amelyeket az EJT-nek napirendre kell tűznie, megfelelő emberi jogi válaszokat keresve. Ezek a következők: a klímaváltozás hatásai, a környezeti erózió és a biodiverzitás csökkenése, a fejlődés és a digitális technológia használata, mesterséges intelligencia, országhatárokon átnyúló bűnözés, korrupció, tömeges migráció, a multinacionális vállalatok növekvő hatalma vagy a globális egyenlőtlenségek jelensége. Ezek az új kihívások a tradicionális emberi jogi gondolkodás átkeretezését igénylik, tekintettel arra, hogy jelentős részük esetében nem tradicionális emberi jogi szereplőkkel is találkozunk. Egyetértés volt abban a tekintetben, hogy az EJT hatékonysága azon múlik, hogy a nemzetközi szintủ döntések és ajánlások lefordíthatók -e nemzeti szintű változásokra. A Glion Human Rights Dialogue résztvevői egyetértettek abban, hogy az EJT KGY általi felülvizsgálata nagy valószínűséggel nem fog változást hozni a Tanács intézményi státuszában. Többen kiemelték, hogy bár a 65/281-os határozat alapján az EJT-nek nem kellene felülvizsgálnia

\footnotetext{
${ }^{102}$ SPOHR (16. lj.) 212.

${ }^{103}$ HRC Resolution 16/21 on the Review of the work and functioning of the Human Rights Council, https://ap.ohchr.org/documents/dpage_e.aspx?si=A/HRC/RES/16/21.

${ }^{104}$ Resolution 65/281 adopted by the General Assembly on 17 June 2011 on the Review of the Human Rights Council, https://undocs.org/en/A/RES/65/281.

${ }^{105}$ Glion Human Rights Dialogue (2019). Glion VI: Towards 2026: Perspectives on the future of the Human Rights Council, https://www.universal-rights.org/wp-content/uploads/2019/04/ Background-Paper-Glion-VI-Botswana-Dialogue-3.pdf.
} 
a saját munkáját, az nem is tiltja ezt meg és ez egy egyfajta belső önértékeléssé válhatna. A résztvevők egyetértettek abban, hogy a legtöbb javasolt változtatás nem igényelné az EJT státuszában, intézményi kereteiben bekövetkező változást. Ezek általában elérhetők lennének a már most is meglévő EJT-mechanizmusok és -eljárások megerősítésével.

\section{AZ EMBERI JOGI TANÁCS MUNKÁJÁVAL KAPCSOLATOS SZAKIRODALMI DISZKURZUS}

Ahogy azt már korábban is említettük a hatékonyság hiánya, valamint a szelektivitás volt az a két fő gyengeség, amit az EJB átpolitizáltsága eredményezett. ${ }^{106}$ Azonban nehéz egy politikai testületet azért vádolni, hogy miért nem tett meg mindent átpolitizáltsága ellen. Mindezek alapján az EJT mint jogutód testület munkáját realisztikusan kell szemlélnünk, nem elkülönítve a reálpolitikától.

2015-ben egy fontos kutatást folytatott a Universal Rights Group, amely bemutatta, hogy az elfogadott EJT-határozatok több mint 55\%-a általános tematikus témákkal foglalkozott, míg az országspecifikus határozatok - amelyek 12 országot érintettek - csak 7\%-át tették ki a határozatoknak. ${ }^{107}$ A kutatás azt is jelezte, hogy a konszenzussal elfogadott határozatok aránya a 2007-es 80\%-ról, 2014-re 69\%-ra csökkent. A szerzők felhívták a figyelmet arra, hogy a III. Bizottság által elfogadott határozatok 56\%-ának van egy megfelelő párja az EJT-ben is és 40\%-uk esetében komoly tartalmi átfedés is tapasztalható. ${ }^{108}$ A III. Bizottság - és nem a KGY plenáris ülésszaka - minden évben elfogad egy rövid határozatot az EJT jelentésével kapcsolatban, amit az Afrikai Csoport terjeszt be. Bizonyos esetekben azonban a III. Bizottság határozata fenntartásokat fogalmaz meg egyes EJT-kezdeményezésekkel szemben, ahogy az történt 2011-ben az EJT 17/19-es az emberi jogok , a szexuális orientáció és a nemi identitás kérdésével foglalkozó határozata kapcsán, vagy 2013ban, amikor a III. Bizottság úgy döntött, hogy elhalasztja a döntést a 24/24-es határozatról, amely az ENSZ-szel, annak képviselőivel és mechanizmusaival történő emberi jogi együttmüködés kérdéséről szólt. ${ }^{109}$ A fenti példákból is látható, hogy az EJT EJB-hez képest új intézményi helyzete bizonyos hátrányokkal is járhat, mivel

${ }^{106}$ Ibrahim SALAmA: „Institutional re-engineering for effective human rights monitoring:proposals for the unfinished business under the »new « Human Rights Council” in Gudmundur Alfredsson - Jonas Grimheden - Bertrand G. RAmchaRAN - Alfred de Zayas (szerk.): Essays in Honour of Jakob Th. Möller. International Human Rights Monitoring Mechanisms (Leiden-Boston: Martinus Nijhoff Publishers, 2009) 186.

${ }^{107}$ Subhas GuJAdHuR - Toby LAMARQuE: Ensuring relevance, driving impact: The evolution and future direction of the UN Human Rights Council's resolution system (Universal Rights Group 2015) 2., https://www.universal-rights.org/urg-policy-reports/ensuring-relevance-driving-impactthe-evolution-and-future-direction-of-the-un-human-rights-councils-resolution-system .

${ }^{108}$ Gujadhur-Lamarque (123. lj.) 3.

${ }^{109}$ Emanuel Bichet - Stephanie Rutz: The Human Rights Council as a Subsidiary Organ: Evaluating its relationship with the UN General Assembly and the UN Security Council (Universal Rights Group, 2016) 7., https://www.universal-rights.org/urg-policy-reports/human-rights-councilsubsidiary-organ-evaluating-relationships-un-general-assembly-un-security-counciV. 
a III. Bizottság újra nyithatja az EJT jelentését. Ilyenre nem volt példa az ECOSOC és az EJB kapcsolatában.

Az EJB/EJT munkájának megítélése összetett kérdés, hiszen ahogy például Krishna Chaitanya Vadlamannati, Nicole Janz és Oyvind Isachsen Berntsen kutatása az EJB/EJT-jelentések hatásairól az FDI-ra (külföldi közvetlen befektetés) is kimutatta, hogy azon országok esetében, amelyeket az EJB vagy az EJT elítélt, körülbelül negyvenkilenc százalékos FDI-csökkenés volt érzékelhető néhány éven belül. ${ }^{110} \mathrm{Az}$ adatokból látható, hogy a világ legfontosabb testülete általi kritika nagyon komoly negatív hatással bír az FDI-ra, sokkal jelentősebb ez a hatás, mint az emberi jogsértés maga, amely természetesen szintén negatív következményekkel jár. ${ }^{111}$ Következésképpen a kritikus EJT-határozatok kézzelfogható gazdasági károkat okoznak az elnyomó rezsimek számára azáltal, hogy elrettentik a külföldi befektetőket. Vadlamannati és kollégái továbbá azt találták, hogy az emberi jogsértésekről szóló médiahíradások szintén fontos szerepet játszanak, felerősítve az EJT-határozatok FDI-ra gyakorolt hatásait. ${ }^{112}$ Mindezek alapján megállapíthatjuk, hogy a nemzetközi emberi jogi testületek, mint pl. az EJT, fontos szerepet játszhatnak abban, hogy a jogsértő rezsimek javítsanak emberi jogi gyakorlatukon.

Érdekes módon Peter S. Henne kutatásai alapján kapcsolatot fedezett fel az EJTtagság és a vallási elnyomás szintje között, kimutatva, hogy az EJT-tagság gyakran a vallási elnyomás növekedésével járt együtt. Mindezek ellenére a kutató támogatta az ezen emberi jogi testületek munkájában való részvételt, az azoktól való elzárkózás helyett. Ez egy fontos konklúzió annak fényében, hogy kutatásai szerint sok ország nemcsak arra használja fel az EJT-tagságot, hogy elterelje a figyelmet az emberi jogi helyzetével kapcsolatos kritikáról, hanem arra is, hogy elfedje egyre elnyomóbb politikáját a vallási csoportokkal szemben. Ebben a tekintetben ez nem kulturális vagy vallási kérdés, hanem a politikai körülmények - ideértve a nemzetközi figyelem mértékét - számítanak. ${ }^{113}$

Sibylle Scheipers úgy vélte, hogy az EJT intézményi keretei az egy exkluzív, konfrontatív testületet vizionáló Észak és az inkább az inkluzivitást és az együttműködést zászlajára tűző Globális Dél közötti intellektuális küzdelmében alakultak ki. ${ }^{14}$

Rosa Freedmannak az volt a véleménye, hogy az EJT új intézményét, nevezetesen a UPR-t és a rendkívüli ülésszakokat - amelyek ugyan nem újak, de jelentőségük jelentősen megnőtt az összehívásuk feltételeinek könnyebbé válásával - a regionális csoportok és egyéb blokkok felhasználják politikai céljaik elérése érdekében. Ezáltal azonban aláássák az EJT azon képességét, hogy teljesítse küldeté-

${ }^{110}$ Krishna Chaitanya Vadlamannati - Nicole Janz - Oyvind Isachsen Berntsen: „Human Rights Shaming and FDI: Effects of the UN Human Rights Commission and Council" World Development 2018. 229., https://doi.org/10.1016/j.worlddev.2017.11.014.

${ }^{111}$ VAdLAMANNATI-JANZ-BERNTSEN (110. lj.) 229.

112 Vadlamannati-JanZ-Berntsen (110. lj.) 234.

${ }^{113}$ Peter S. Henne: „Does the UN Human Rights Council help or hurt religious repression?” Journal of Church and State 2018. 60/4. 723-724. https://doi.org/10.1093/jcs/csy005.

${ }^{114}$ Sibylle ScHEIPERS: „Civilization vs. toleration: The new UN Human Rights Council and the normative foundations of the international order" Journal of International Relations and Development 2007. 237-238. https://doi.org/10.1057/palgrave.jird.1800125. 
sét, nevezetesen az emberi jogok előmozdítását és védelmét. Friedman az OIC-t és az Afrikai Csoportot emelte ki, mint két meghatározó csoportot, amely arra használja az új mechanizmusokat, hogy elterelje a figyelmet emberi jogi helyzetéről. ${ }^{115}$

Marisa Viegas e Silva az EJT első hat évét követően azt az álláspontot képviselte, hogy a Tanács körüli politikai környezet megfelel a nemzetközi kapcsolatok realitásainak. ${ }^{116} \mathrm{Az}$ ő értékelése vegyesebb volt, mint a korábban említett szakértőké, mivel ő kiemelte az EJT félig állandó jellegét (vagyis az ülésszakok EJB-hez képest hosszabb voltát), a tagok megválasztásában bekövetkezett változásokat, valamint annak lehetőségét, hogy felfüggesszék a jogsértő ország tagságát, valamint a UPR-t a pozitív változások között. A másik oldalon az a tény, hogy az EJT megismétli az EJB hibáit - úgy is mint a túlzott átpolitizáltság, a kettős mérce vagy a testület kormányközi jellegének erősödése, amely a civil társadalom által játszott szerep csökkenéséhez vezet - szerepelt az EJT felállításával kapcsolatos negatív következmények között. ${ }^{117}$ Theodor Rathgeber nagyon élesen kritizálta az EJT-t. „Az EJT nem rendelkezik sem hitelességgel, sem hatékonysággal, és a tagországok jelentős része még mindig mérsékelt érdeklődést mutat az ellentmondásos kérdések megtárgyalása iránt."118 Úgy vélte, hogy a Globális Dél rosszul értelmezett szolidaritása megakadályozza az érdemi emberi jogi ellenőrzést az EJT által. Kiemelte, hogy az EJT mint politikai testület létrehozatala atipikus jelenség, mivel annak mandátuma egyszerre tartalmazza a „tények kiderítését, az értékelést és a tárgyalást”. Álláspontja szerint a speciális eljárásoknak, az NGO-knak, valamint az OHCHR-nak sokkal fontosabb szerepet kellene kapniuk annak érdekében, hogy javuljon az EJT teljesítménye. ${ }^{119}$

Végezetül Eric Cox nagyon világosan fogalmazott, amikor kijelentette, hogy „Nem várhatjuk, hogy az EJT eltérően müködjön az EJB-hez képest, mivel mindkettő alapvetően politikai testület, amely visszatükrözi a tagság akaratát." ${ }^{120}$

\section{KONKLÚZIÓ}

Egy olyan politikai testület, mint az EJB nem tehetett többet, mint amit a tagállamok lehetővé tettek számára, és nem lehetett hibáztatni azért, mert politikai megközelítéseket követ. A nemzetközi közösség ennek ellenére úgy határozott, hogy felváltja az EJB-t egy másik testülettel, mivel számos tagállam úgy gondolta, hogy az új intézményi keretek alkalmasak lesznek az előző testület politikai hiányosságainak orvoslására. Mindezek után nem volt meglepő, hogy egy új testület a korábbi-

${ }^{115}$ Rosa FreEdman: „New Mechanisms of the UN Human Rights Council” Netherlands Quarterly of Human Rights, 2011, https://doi.org/10.1177/016934411102900303.

${ }^{116}$ Marisa Viegas E. Silva: „The United Nations Human Rights Council: Six years on” SUR International Journal of Human Rights 2013. 110.

${ }^{117}$ SiLVA (116. lj.) 109.

${ }^{118}$ Theodor RATHgEBER: „Ambiguity as a main feature: The UN Human Rights Council in 2009” in Wolfgang BenedeK - Florence Benoit-Rohmer - Wolfram KarL - Manfred NowAK (szerk.): European Yearbook on Human Rights (European Academic Press, 2010) 193.

${ }^{119}$ RATHGEBER (118. lj.) 193.

${ }^{120} \operatorname{Cox}(47$. lj.) 89. 
val szinte teljesen megegyező mérettel, ugyanazon szereplőkkel és hasonló politikai körülmények között nem hozott áttörést az emberi jogsértések elleni nemzetközi küzdelemben. A UPR életre hívása azonban új megközelítéssel gyarapította az ENSZ egész rendszerét, biztosítva valamennyi tagállam emberi jogi helyzetének áttekintését egy együttmüködésen alapuló eljárás keretében, a UPR-ajánlások végrehajtása során egyre fokozottabb szerepet biztosítva a technikai segítségnyújtási pillérnek.

A szakirodalomban méltatlanul kevés szó esik az EJT-ülésszakok ún. kísérő rendezvényeiről, amelyek gyakran az egyetlen olyan fórumot jelentik, ahol a P5-ökhöz kapcsolódó érzékeny emberi jogi problémák (Guantánamo, Tibet, Csecsenföld) is napirendre kerülhettek. A civil társadalom állt legtöbbször ezen rendezvények mögött, emberi jogvédőket és áldozatokat hozva Genfbe, felhívva olyan emberi jogsértésekre is a figyelmet, amelyeket az EJT plenáris ülésszakain a tagállamok nem is tárgyaltak.

Az EJT folyamatosan bővülő napirendje nem tartható fenn. Nagy szükség lenne egy komolyabb profiltisztításra, amely során bizonyos kérdések - mint például a mérgező hulladékok vagy a külföldi adósságok kérdése - más, sokkal inkább kompetens ENSZ-testületekhez kerülhetnének át. Néhány, már korábban említett tematikus mandátum megszüntetésére szintén szükség lenne az EJT hatékonyságának növelése érdekében. Ez elérhető lenne ún. „sunset” klauzulák (napnyugta záradék) által, amelyek jeleznék, hogy az adott határozat által érintett témákra nincs a továbbiakban szükség az EJT napirendjén, és azokkal a továbbiakban más ENSZtestületek foglalkozzanak.

A UPR-folyamat életre hívása semmilyen körülmények között nem tette szükségtelenné az országspecifikus határozatok elfogadását; azonban a „naming and shaming”-re sokkal stratégiaibb módon kellene sort keríteni, az ENSZ rendszerén belül jobban egyeztetve, a regionális dimenzió jelentőségét növelve a világszervezet munkáján belül. A jelenlegi gyakorlat, amely értelmében az országhelyzetekkel foglalkozó 4-es napirendi pont alatt beterjesztett határozatok egy részét a politikai nyomás miatt a technikai együttmüködéssel foglalkozó 10-es napirendi pont alatt terjesztik be, csak akkor fogadható el, ha tényleg kézzel fogható javulásokról lehet beszámolni az adott ország emberi jogi helyzetében.

Politikailag nem lenne reális arról álmodoznunk, hogy az EJT a tökéletes emberi jogi gyakorlatú országok klubjává váljon, de az emberi jogok ügyét támogató kormányoknak bátorítaniuk kell azon országok jelölését, amelyek pozitív politikai célként tekintenek az emberi jogok védelmére és előmozdítására.

Az EJT egy másik érdekes sajátossága, hogy az Afrikai és az Ázsiai Csoportok meghatározó befolyása ellenére, valamint a Nyugat meglehetősen visszafogott helyzetére a Tanácsban, még mindig számos a Nyugat által támogatott vagy kezdeményezett fontos tematikus és országspecifikus határozat fut az EJT-ben. Ezenkívül az EJB normaalkotó munkája folytatódott az EJT-ben is. Ezek a pozitív fejlemények nagyrészt annak eredményei, hogy a Tanács munkájában egyre fontosabb szerepet töltenek be a különböző régiók közötti koalíciók, amelyek átlépnek a tradicionális Észak-Dél megosztottságon. Számos fontos, érzékeny kérdésben a WEOG-nak, az EEG és a GRULAC többségének, valamint az emberi jogok ügyére pozitívan tekin- 
tő afrikai és ázsiai országoknak sikerült koalícióra lépniük. A világon megfigyelhető demokratizálódási folyamat, amely időszakos visszaesések ellenére ${ }^{121}$ remélhetőleg tovább fog folytatódni, ezeket a kedvező folyamatokat erősítheti, javítva az EJT összetételét, mivel egyre több demokratikus ország próbál majd bekerülni az EJT-be.

Végezetül hadd emeljem ki, hogy a nemzetközi közösségnek mindent meg kell tennie az EJT megelőző szerepének erősítése céljából, stratégiailag használva a speciális eljárások és a UPR-folyamat során keletkezett adatbázisokat. Az EJT jobb összetétele, kiegészülve a régiókon átívelő együttműködések szerepének növekedésével és a „naming and shaming”, valamint a technikai együttmüködés megfelelő arányának biztosításával az EJT-t még alkalmasabbá tehetik fontos mandátumának végrehajtására az emberi jogok nemzetközi védelmével és előmozdításával kapcsolatban.

${ }^{121}$ A Pew Research szerint 2017 végén a legalább 500000 lakosú 167 ország, 57\%-a demokratikus berendezkedésü volt, 28\%-a vegyes, míg összesen csak 13\%-a számított autokráciának. Ez a demokratikus hullám a 70-es évek közepén kezdődött és bár az elmúlt években visszaesés volt tapasztalható a számok még mindig nem hasonlíthatók össze az 1976-os adatokkal, amikor az országok 62\%-a számított autokráciának, 25\%-a volt demokratikus és 13\% tartozott a vegyes rezsim típusába, https://www.pewresearch.org/fact-tank/2019/05/14/more-than-half-of-countries-aredemocratic/. 